\title{
Spatial Policy in Natural Resources Governance
}

\author{
Reniko Gondo $^{1, \text {, }}$, Ezra Pedzisai ${ }^{2,3}$ \\ ${ }^{1}$ Department of Natural Resources Management, Okavango Research Institute-University of Botswana, Maun, Botswana \\ ${ }^{2}$ Geography Department, Bindura University of Science Education, Bindura, Zimbabwe \\ ${ }^{3}$ Disaster Management Training and Education Centre for Africa, University of the Free State, Bloemfontein, South Africa
}

\author{
Email address: \\ rgondo@ori.ub.bw (R. Gondo), epedzisai@gmail.com (E. Pedzisai) \\ ${ }^{*}$ Corresponding author
}

\section{To cite this article:}

Reniko Gondo, Ezra Pedzisai. Spatial Policy in Natural Resources Governance. International Journal of Environmental Protection and Policy. Vol. 4, No. 5, 2016, pp. 141-154. doi: 10.11648/j.ijepp.20160405.15

Received: July 9, 2016; Accepted: August 3, 2016; Published: September 29, 2016

\begin{abstract}
Governance of natural resources includes issues of power, use, access and most importantly, responsibility. While many people assume natural resources to be free and open for all, most natural resources are in fact under form of governance, be it official or unofficial. Available studies are generally critical about the overall management and interaction of ecosystems. Many studies are concerned with biodiversity interaction and management and conservation methods. With the objective of exploring the ways through which geographical technologies could be applied to influence spatial policy on natural resource governance, this article critically examined the issue using both secondary and primary data. Secondary data collection included the extraction of temporal remote sensing Google Earth images (1979 to 2014) used to thematically map features by onscreen digitising using visual image interpretation and confirmed by ground truthing fieldwork. The electronic spatial database created was then used to map the spatial extent of the lake, human activities including infrastructure development and gardens close to the lake for the period. Primary data were collected using fieldwork conducted to ground truth the present activities and man-made features near the lake. The method also reviewed available spatial and temporal secondary data. The article therefore demonstrates the importance of spatial technologies in natural resources management with a special reference to the critical and internationally recognised Lake Ngami on the north western Botswana.
\end{abstract}

Keywords: Biodiversity, Governance, Lake Ngami, Natural Resources, Spatial Technology

\section{Introduction}

Lake Ngami, a natural dead end water body without outflow [1], situated in the Kalahari Desert to the South of the famous inland Okavango River Delta [2] located in Ngamiland District of North western Botswana [3-4]. It receives most of its water as a result of tropical rainfall to the north in Angola that feeds the Okavango River, which overflows into the lake [5]. The flood waters actually reach the lake during the southern hemisphere winter months or dry season [6]. Lake Ngami was at times substantially larger during the Pleistocene and Holocene and was part of the large palaeo-lake Makgadikgadi that covered much of central Botswana [7-8]. It was also a large body of water that was connected via the Thamalakane River to the Mababe Depression, located about $180 \mathrm{~km}$ to the northeast of Lake Ngami [9].

On 22 June 2014, the Okavango Delta became the $1000^{\text {th }}$ site to be officially inscribed as a United Nations World
Heritage. The lake is surrounded by people from five ethnic groups namely the Hambukushu [10], noted as Mambukushu according to Stigand [4], later Mampukushu according to Stigand [11] and Mbukushu [12], Dcenku, Wayeyi, or Bayeyi according to Larson [13], Bugakhwe and Ilanikwe [10, 13], each with distinct ethnic identity and language [13]. The Hambukushu, Dcenku and Wayeyi have traditionally engaged in mixed economies of millet/sorghum agriculture, fishing, hunting and the collection of plant food and pastoralism [10]. On the other hand, the Bugakhwe and Ilanikwe are 'Bushmen' who have traditionally practiced fishing, hunting and the collection of wild plant food. Bugakhwe people utilized both forest and mineral resources [10]. Clearly, despite these imminent differences in lifestyles of the five ethnic groups, it is clear that all these activities have a serious impact on the life and sustainability of the lake especially in the desert condition in which it is geographically located. Schwarz [14] records six ethnic 
groups as follows; 1) Bechuanas comprising Batawana, Bamangwatos, and Bahrutsis, 2) Damaras, 3) Makubas, Mananswas, 4) Bakalahadi, 5) Makalakas, and 6) the seven clans of Bushmen including river Bushmen known as Tannekhoe. Those earlier identified tribal groups differ from the latter but this disparity may not be very significant due to history and social interactions. Spatial technologies then become an indispensable tool to understand the spatial change type and direction as well as policy formulation that helps in governance and management of the water resource. Historically, Andersson [15-16] detailed other earlier occupiers including the Bayeye, Ngami, among others. Stigand [4] noted that Lake Ngami was part and parcel of Bechuanaland Protectorate which implies that policy on its exploitation may not be a new phenomenon. Consistent with this thesis, Lake Ngami was mapped by Schwarz [14] as part of Batawana Reserve. However, emerging changes coupled with climatic and anthropogenic dynamism have a on the implications especially towards the rich biodiversity. It is an important biodiversity hotspot.

Lake Ngami is both a permanent and seasonal home to a wide variety of wildlife. Wild animals include elephants, buffaloes, hippopotamus, lions, cheetah, tsessebe and many others are found in and around the Okavango Delta. A description of the waterfowl (duck, geese,) different species cormorants, pelicans, flamingos, reptiles, fish, many animals and related human activities since historical times as early as late 1850s [2, 15-18]. This ecological function has made it a popular tourist attraction and ultimately classified internationally designated as as a World Heritage centre.

\subsection{History of Lake Ngami}

Ngami is a Sekuba name given by the Makuba meaning "a very large expanse of open water" [11: p2]. "Noka" (river) ea "Botletle" (Bushmen tribe) therefore meaning, river of the Bushmen [14: p529]. Lake Ngami which was once a permanent water body is said to have been discovered by Livingstone and accomplices in 1849 [19]. Various data were put together in order to make a long term environmental monitoring in the Okavango Delta for proper natural resources governance. This section of the article looks at the sources of information for understanding the history of Lake Ngami. It describes various sources of information that can help us understand the Lake and make a long term environmental monitoring plan in the Okavango Delta.

\subsection{Historical/Archival Records 1849-1966}

The following section describes in detail the various data sources which fall within the two major data sources as depicted on Figure 1.

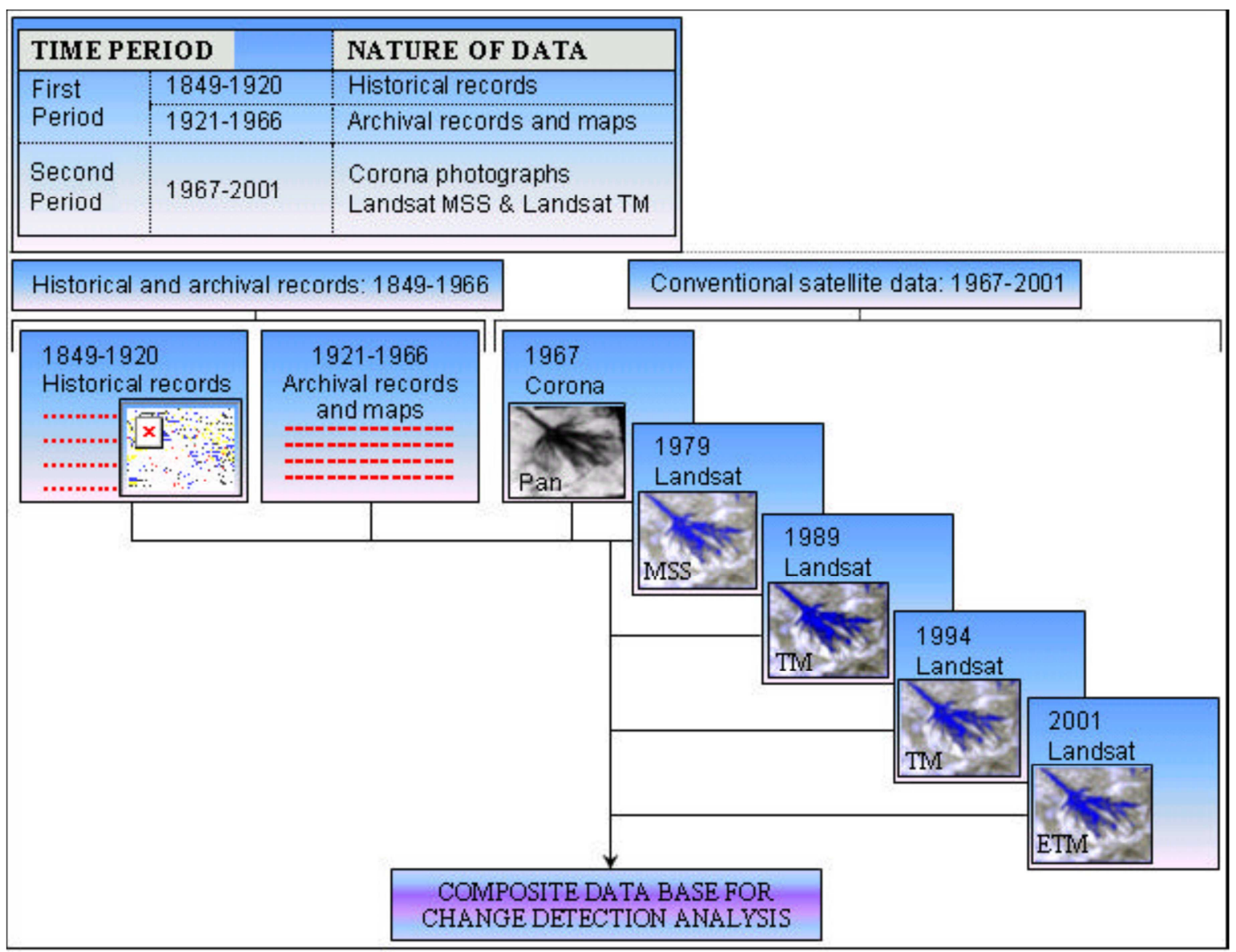

Figure 1. Archival/Historical records and satellite data for long term environmental monitoring in the Okavango Delta: 1849-2001 Source: [20: p3]. 
Figure 1 shows a schematic outline of the structural layout of the database that has been compiled for monitoring environmental changes in the Okavango Delta. Using this schematic diagram a summary of the database can be made and come up with two distinct periods of sources of database. Hamandawa et al. [20] has grouped the periods into two categories of which the first one comprised of archival records and maps and geocoded information compiled from historical and colonial records. The second period of data set includes conventional remote sensed data. These two groups of data periods can help us to have a lot of information concerning Okavango Delta.

The data for this period are subdivided into two superiors [20-22]. This section of the article critically reviews how historical records can be used to complement the remote-sensed data at our disposal by extending the time horizon to periods predating satellite photographs and images According to Ringrose et al. [23] archival records can be in the form of sketch drawings and archival maps or published and unpublished records by early travellers, hunters, missionaries and explorers. Sketch drawings and maps as shown on Figure 2 are a source of valuable information which can be used to complement conventional recent and current satellite data for proper management of natural resources of Okavango Delta. A careful study of the drawings such as Figure 2 provides useful pointers on general environmental conditions in the past which can allow us to make meaningful inferential analysis of the Okavango Delta. If such illustrations are used in conjunction with historical information from published and unpublished records, it is possible to extend temporary coverage by several decades [20] in terms of data acquisition to periods predating convectional remote sensed data from different platforms. Although information of this nature is mostly qualitative, the same information can be captured in Geographical Information System (GIS) to provide spatially referenced dataset. GIS has unique spatial analyses methods and is a diverse toolbox which is evidently applicable for the purpose. Figure 2 shows a sketch diagram of historical data useful for understanding the resource.

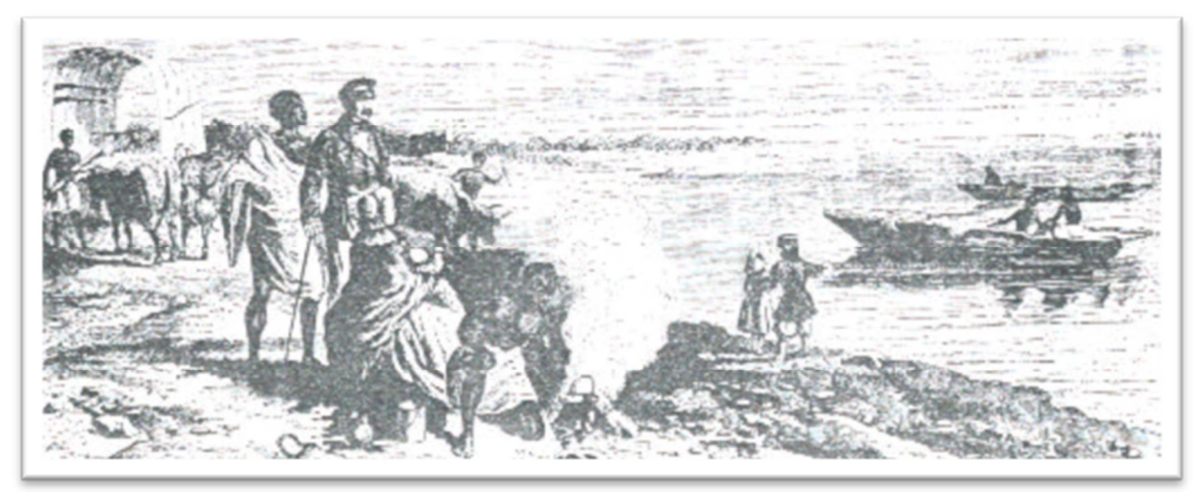

Figure 2. David Livingstone and his Family at Lake Ngami in 1849. Source: [24].

Figure 2 provides a wealth of information about Lake Ngami. Boats in the extreme right of the drawing confirm the presence of substantial water volumes to some reasonable depth. Whilst the diagram might appear as an ordinary one, a careful scrutiny of it would reveal a wealth of information which would assist in the monitoring of water and other resources within the Okavango Delta. Similar historic records as in Figure 3 were equally important.

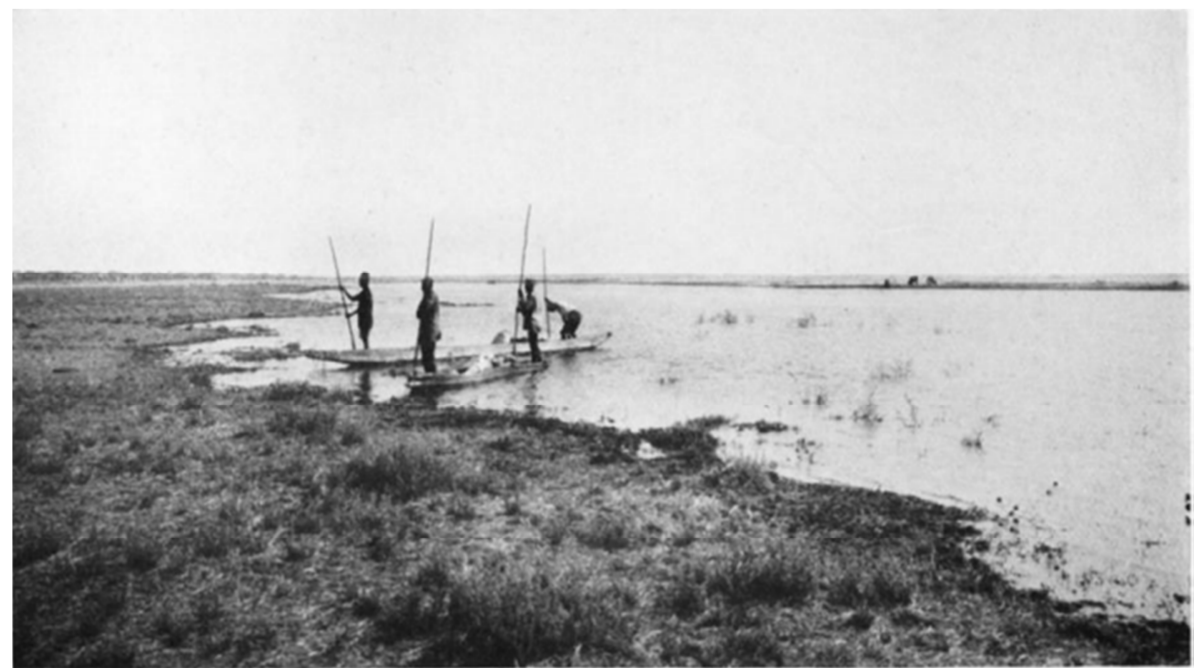

Figure 3. Lake Ngami near point first reached by David Livingstone, Source: [14: p533]. 
Information to understand the whole of Okavango Delta or the Lake Ngami in particular can also be derived from archival maps (Figure 4). These maps are often ignored because of the tedious efforts required to capture them in a GIS system [20, 25].

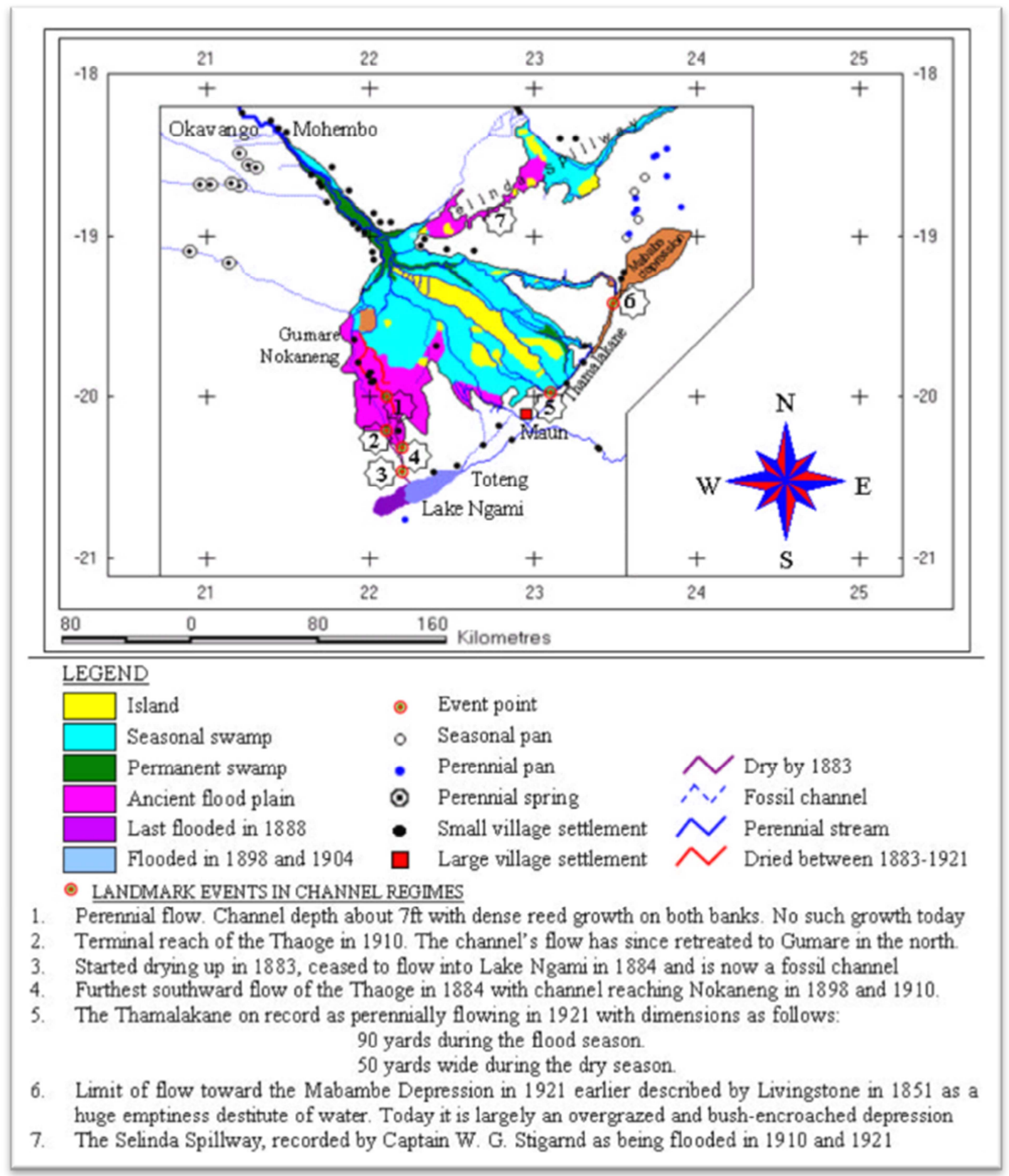

Figure 4. Composite reconstruction of the surface water situation during the first half of the 20 ${ }^{\text {th }}$ century, Source: [26: p66].

For instance, Figure 4 was reconstructed from two maps sourced by MacDonald [26] from the Botswana National Archives [20]. To come up with the map (Figure 4) hard copies of the maps were acquired and were digitised and mosaicked into a computer to produce one composite map [20]. The details appended to the map in the form of landmarks in channel regimes were post-scripted to the maps on the basis of information sourced from historical records.

The state of the environment in Lake Ngami and Okavango Delta at large can also be derived from early travellers' records. The richness of historical and archival records is clearly presented in Andersson [15-16] in an expedition that was undertaken initially as a pair with $\mathrm{Mr}$ Francis Galton and later returning alone. The author presents 
a rich amount of information on land and aquatic organisms. Andersson [15-16] detailed in his detailed text book the two explorations and various discoveries (on western perspective) of the various aspects of the Ngami landscape and economy, politics, lifestyles, religion, culture, etc. the detailed outline shown diverse and abundant life forms including mammals, (such as lion, giraffe, wild dog, hippopotamus, rhinocerous, oryx, eland, elephant, wild boar, zebra wild beasts, leopard, baboons, hogs, antelopes), abundant wild fowl and birds (ostrich, guinea fowl, flocks of doves, ducks) insects (locust, wild bees, caterpillar swarms, termites, including disease vectors such as tsetsefly) and various fish species. Stigand [11] also confirmed especially of large game and acquatic species similar to those of Andersson [15-16] although narrated more of the dangerous hippo. The love and cruelty also of various people including the chiefs and their subjects, dangers in everyday and in livelihood styles, are very well outlined. Hellard et al. [1], on their study on avian malaria (Plasmodium and Haemoproteus), used 176 wetland associated birds species and 3414 that were captured at Lake Ngami. Robbins et al. [17-18] later confirmed the rich biodiversity comprising terrestrial and wetland mammals, fish, reptiles, and birds, including domestic animals of kind, among others of the Ngami area using archeaological evidence. Activities such as farming grain, fruit collection, hunting wildlife, fishing, drinking liquors, clothing, (dresses and ornaments), homes of the Bayeye tribe for example are clearly detailed in this detailed publication [16]. This is the same tribe recorded as Bayeyi by Larson [13] a Bantu speaking people originally from Zambia. Larson [13] further identified 12 clans and Maun very close to the lake.

\subsection{Mapping Lake Ngami}

There were several attempts to map this important lake. Figures 5a, b and c show the temporal impression map of Lake Ngami for the years 1906, 1922 and 1932 respectively. It is important to note that some of these maps were less accurate as they were drawn with free hand and GIS was not applied then. It should however be noted that the importance of Lake Ngami has ever been overshadowed by the Majestic inland delta Okavango. Many explorers who came to know Lake Ngami were usually attracted by the Okavango Delta. It is therefore important to note that most of the maps show Lake Ngami as a smaller subsystem of the greater Okavango Delta. Explorers were the most influential geographers of the time (see Andersson [15-16].

If it is systematically added to a spatially referenced information system, historically information helps to shed more light on environmental conditions in the past [20,27]. Environmental variables useful for purposes of long term monitoring often captured in historic documents include wildlife, vegetation and water distribution [23]. In most cases, diarised information has been compiled and is often accessible in published form in archival records. Although the accuracy of such information is often difficult to ascertain, individual records can be cross-checked against each other to provide dependable reconstruction of environmental conditions in different places. Science has often developed new and relevant methods to use in search of answers and solutions to persistent problems such as carbon dating, forensics among. Use of such scientifically calibrated and validated methods could then be useful in such circumstances.

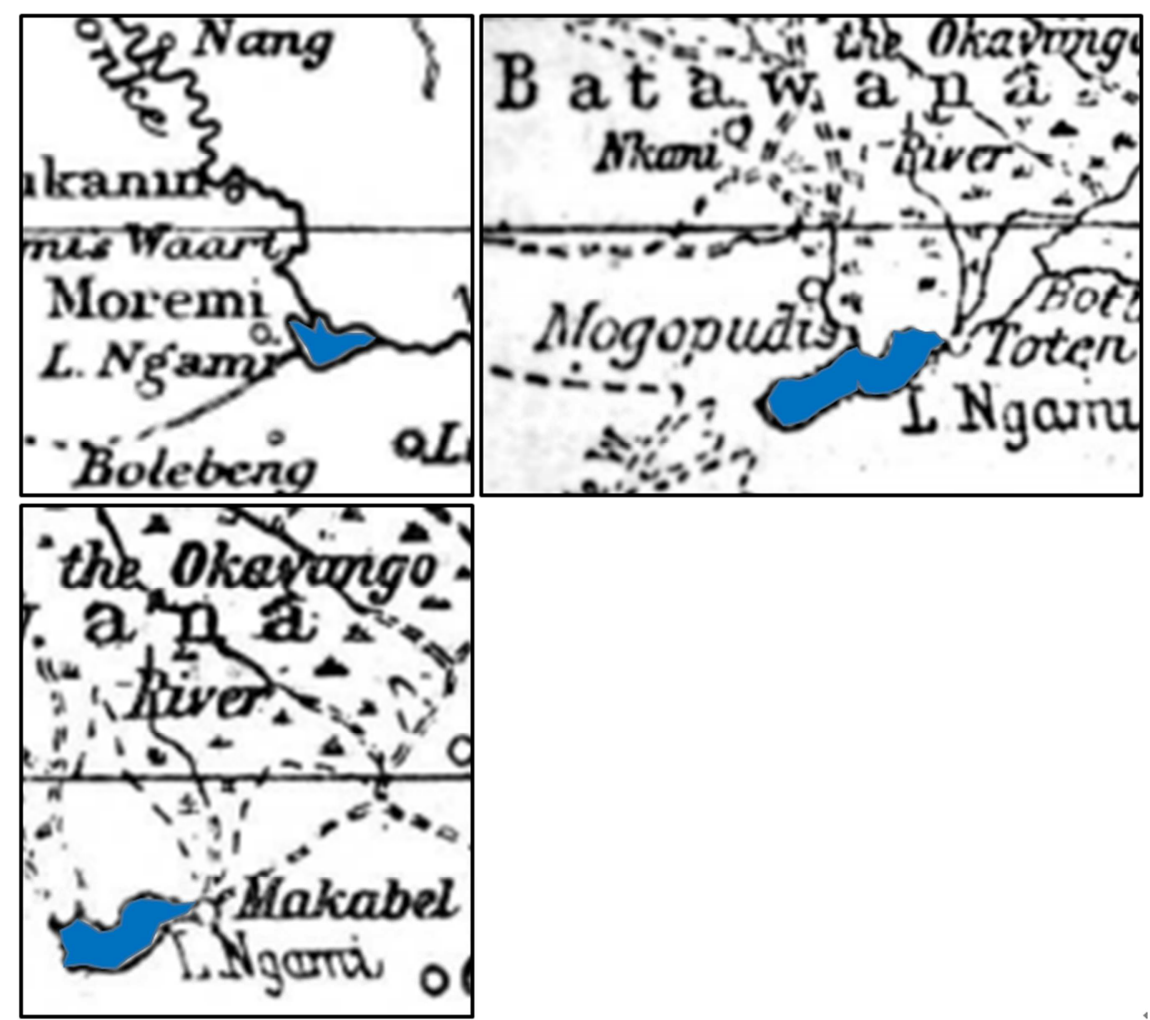

Figure 5. Map of lake Ngami for the years 1906, 1922 and 1932, Sources: [28-30]. 
Additional information is also retrievable from colonial documents that often provide reliable records on a wide range of environmental factors such as population distribution, the occurrence of droughts and disease out-breaks in different areas [26]. Colonial (written) records can be incorporated into a geo-database and used to complement convectional forms of remote-sensed data. If colonial documents are captured into a GIS, it is also possible to create new maps on the basis of historical information.
Mappable historical information might be in the form of specific events whose exact location is captured in written form [25-26]. With historical information of Lack Ngami on various forms of human interaction accessible to us in the form of written records, it is possible to devise a methodology in which scattered information for specific areas can be compiled and captured into maps to give a spatially geo-referenced records [22]. Figure 6 shows a map of Okavango Delta prepared with some GIS application.

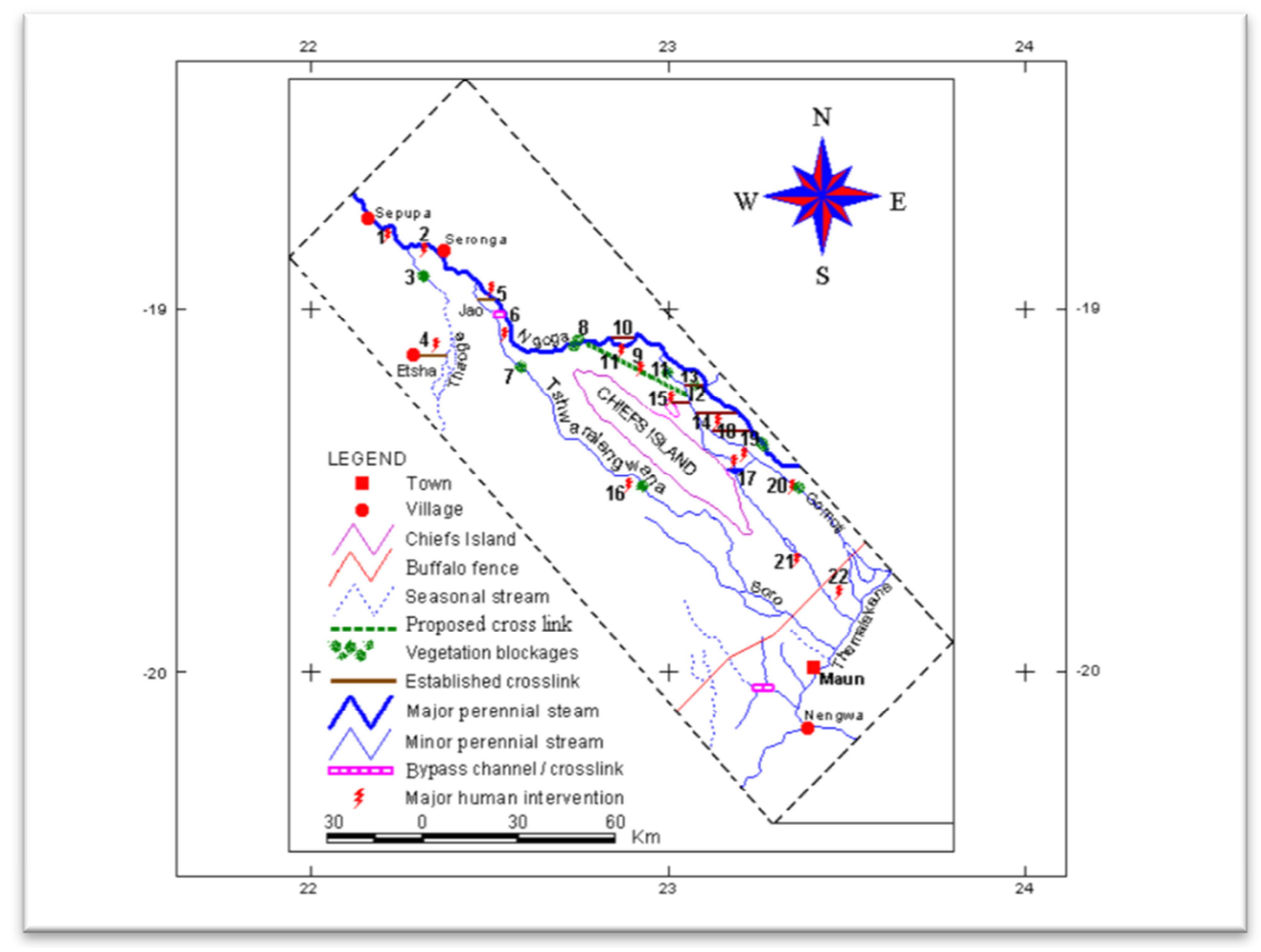

Figure 6. Historical Human intervention of Okavango Delta, Source: [20].

Figure 6 shows the extent of human intervention during and after the Ngamiland Waterways Project of the early 1950 s $[20,23,27]$. Shown on the map is a naturally induced vegetation blockage in the Okavango delta, distributary channels in the east while human interference is often considered to have little influence on changes in the Okavango Delta. Evidence captured in this illustration suggests that planned diversion of channel flow towards specific settlements such as Maun might have accelerated the desiccation of the Mababe Depression [20].

\subsection{Background to Natural Resources Governance}

Governance is a critical determinant of equity, justice and effectiveness in biodiversity conservation and of the contribution that natural resources make to people's enjoyment of rights and development opportunities. Governance is at the root of many problems that people are experiencing today, including natural resources related conflicts [31]. International Union of Conservation of Nature (IUCN) [31] defined natural resources governance as the interactions among structures, processes and traditions that determine how power and responsibilities are exercised, how decisions are taken and how citizens or other stakeholders have their say in the management of natural resources. Natural resources governance framework addresses the set of norms, institutions and processes that form decision making and citizens' engagement in policy development in policy development and how its implementation impacts nature and 
people. In this case we are provided with a basis for understanding how governance in the real world affects livelihoods, food security, climate adaptation, human wellbeing and how natural resources interventions can facilitate and support positive change.

\subsection{Spatial Technologies}

Desktop mapping is a narrow description for what now encompasses a broad suite of spatial tools used for a variety of natural resources management, research, and planning activities. Spatial technologies include Geographic Information Systems (GIS), Global Positioning Systems (GPS), remote sensing, and spatial data management. Many studies integrate GIS, GPS, and remote sensing with natural and spatial analyses for natural resources assessment, water quality monitoring, wetland modelling and restoration, groundwater evaluation, decision support, and a wide range of other hydrologic applications.

Creating a baseline, or "library," of existing spatial data sets can be the first step in an ecosystem services assessment. Some of the physical data which exist for most areas include: topographic information (used to assess the landscape); hydrologic units (hydrologic basins for relatively large areas); hydrologic data (stream networks); and, soils data (soil types and permeability). Additionally, remote sensing data (images or aerial photographs) can be incorporated into the baseline data to provide a synoptic coverage of ecosystem services. These data can be used to provide a spatial reference for air and water quality monitoring sites, assess physical characteristics of the Lake before field studies, plan field data collection efforts, and provide input parameters for ecosystem services modelling. Other spatially referenced information, such as road networks, census data, land ownership, political boundaries, and tax parcels may be used in conjunction with spatial data layers and field data to support decision making systems within Lake Ngami. The following section is going to discuss the main spatial technologies mainly used in the management of ecosystem services.

\subsubsection{Remote Sensing}

Remote sensing is the art and science of obtaining information about an object or feature without being in direct physical contact with it [32]. Conventionally refers to recording electromagnetic radiation using aerial photography for visual analysis and digital (non-photographic) imagery for computer-aided analysis. Remote sensing is very important in natural resources management as it enable us to have many details regarding the resources. With remote sensing a complete historical record of resources can be made and it reduces the field work exercises which can be costly. Remote sensing is a rapid means of getting information.

\subsubsection{Global Positioning Systems (GPS)}

GPS is defined as satellite system used to record positions (earth coordinates) of point, line, or area features on the earth's surface. GPS consists of space segment (satellites), control segment (ground monitoring), and user segment (GPS receivers). The following are the uses of GPS. It is used in defence and was originally developed, and controlled by, Department of Defence for submarine navigation [32]. In recreation it is used for hiking, fishing, and hunting. Furthermore, it is a data collection tool for GIS and is a mechanism for capturing, updating, and editing GIS data. It is used for geographic accuracy as it links spatial data with real the world.

\subsubsection{Geographic Information System (GIS)}

GIS is a collection of hardware, software, geographic data, and personnel designed to capture, store, organize, update, manipulate, analyse, and display geographically referenced information [33]. Having defined GIS as one of the spatial technologies the question which comes to our mind is why is GIS important. According to Schrenk [34] GIS is used to maintain and retrieve large quantities of data. This implies that in Okavango Delta it would be possible to use GIS to retrieve data on wild animal movement and habitat. Furthermore, GIS is important in that it is used to manipulate spatial and related tabular data and to perform complex spatial analysis as well as rescale data for analysis. It is through use of GIS that the creation of thematic maps (maps which depict a specific theme such as soil type around Lake Ngami area) is made possible. GIS is capable of map production which allows the user to design and display maps, charts, tables and images on screen and print maps to a variety of printing and plotting devices. With GIS it is able to integrate maps, images, tabular data, graphics, and charts into cohesive displays for viewing and evaluation. Other capabilities of GIS are the changing of map colours and symbols, viewing and printing geographic data at user designed scales and size, searching and selecting geographic features of interest based on subject queries, logical queries, arithmetic queries, and spatial relationships.

\subsection{Benefits of Spatial Technologies}

Remote sensing, GPS and GIS have more benefits as compared to traditional data collection and analyses methods. Remote sensing is capable of measuring, recording or observing phenomena from a distance. Aerial photographs and satellite images have provided numerous advantages for science and applied scientific products. The benefits include vantage point synoptic viewing hence increased spatial coverage, revisit period (temporal resolution) allowing historical record data collection, ability to stop action, cost saving and rapid data collection, reduction of data access by restriction not needed, and adjustable spatial resolution. There is a wider selection of data providers including from both active and passive remote sensing to obtain data from and application often depends on the nature and scale of data. This has seen remote sensing data applied across scientific discipline divide and natural resources is not an exception. GPS has been applied in monitoring and management of various 
movements in vehicles and animals. In animals, collaring of large mammals is popular in many game reserve areas; GPS is applied to monitor movements of animals and their behaviour. GIS which is made up of several basic functions including data capture which is critical for recording various resource components. Populations of organisms in and around Lake Ngami can be efficiently recorded or captured using data capture function of the GIS. Once the data are captured, another important function is the data base function. There are several advantages driven from an electronic spatial database as compared to the traditional storage and retrieval. This is important for data storage, updating, organisation and retrieval function which are often tedious, untidy, and demanding lots of storage space. Electronic spatial database is compact with data stored on hard discs, memory devices (cards, sticks, CDs, DVDs and recently introduced cloud storage on virtual platforms) as compared to the traditional space demanding, manual data storage and retrieval. Traditionally, files and folders are stored in large cabinets and the data are easily distorted due to weather, pests (eg rats), bad handling (eg folding maps, repetitive extraction and use by often many different people) just to mention but a few. The traditional database is difficult to update, edit and upgrade without going through the tedious time consuming and inefficient catalogue retrieval system manually. Electronic spatial databases make data capture, organisation and management and retrieval efficient and easy. Data security is enabled by use of user privileges and restrictions using role definition and passwords. Data is also easy to share since it is uploaded on the server and all users can access as long as they remain in the network of the database system. Spatial databases are often associated with easy and efficient back-up and recovery functions thereby reducing data losses due the application software using for the database architecture. Data redundancy is also eliminated due to normalisation of relations for instance. Access level can easily be controlled by definition of user rights and privileges in the database. Therefore spatial databases are associated with multi-tasking, multi-use and easy of access by efficient retrieval using structured query language (SQL). These are important in resource management for decision making. Spatial databases are therefore important for start-off point in sound decision-making especially in natural resources monitoring, evaluation, and management. Decision making should be based on scientifically-modelled and analysed information rather than speculative and unsubstantiated claims. However, there is need also to be careful of shortcomings of the technology based spatial databases.

The challenges associated with databases include centralising the risk of data corruption by those who have privileges to edit and delete the database. As a computer based technological function, the quality of the information is influenced by the input quality, hence the computer adage, garbage-in-garbage-out (GIGO). Errors incorporated during data capture and processing and analyses will manifest in the final map produced. It is difficult to eliminate human error and lack of skill. Regular training and retraining, consistent practice become imperative and these require resources. Establishment and maintenance of the database is often a challenge with many users. Information and communication technology is fast changing and hence the softwares, hardware, and data require updates and refurbishment while softwares could be affected by computer viruses. Cyber-crime is another big challenge.

Once the database has been established, the various spatial analyses can then be performed and these vary according to the type of phenomena. GIS is able to measure location by identifying coordinates, distance (shortest or longest) and perimeter and area. It can classify landcover and understand spatial and temporal variations. Resource degradation can be efficiently determined. Network analyses can trace movements and flows in one and multi directions. Overlay analyses can integrate different factors as maps and identify suitable locations. Such an application can be used for instance to determine the breeding grounds of organisms, area threatened by degradation and area of different land cover. Neighbourhood analysis is whereby proximity to particular resources influences the utilisation are assessed. Buffer zones can be generated using specific scientific factors and hence understand degradation and help make sound management decisions. Once the analyses have been performed, the information is often communicated using maps. Cartographical function of the GIS helps produce simple but factually correct maps that politicians, resource managers and other relevant stakeholders could use for correct and sound decision making in order to ensure sustainability of the natural resources. It is evident that spatial policy on resource governance will be incomplete without application of spatial tools and technologies especially for such an important resource as the Lake Ngami. Spatial technologies are important to influence correct spatial policy.

\section{Spatial Policy}

According to Collins English Dictionary [35] spatial means relating to space, for example, the spatial distribution of population means how is the population distributed over space. It is a word which is related to space. It refers to something existing in or occurring in space or having extension in space [36]. Therefore spatial has to do with space the distance between things. On the other hand a policy is defined as a course or principle of action adopted or proposed by an organization or an individual. It is a plan or course of action of government, political party or business intended to influence and determine decisions, action and other matters. In this regard a spatial policy is can be defined as any government plan or course of action on Lake Ngami. It refers to a course of action or principles of action adopted in the management of natural resources occurring in and around Lake Ngami, in Botswana or anywhere else. 


\subsection{Natural Resources}

Natural resources are naturally occurring substances that are considered valuable in their relatively unmodified (natural) form. A natural resource's value rests in the amount of the material available and demands for it. The latter is determined by its usefulness to production. A commodity is generally considered a natural resource when the primary activities associated with it are extraction and purification, as opposed to creation [37].

\subsection{Classification of Natural Resources}

Natural resources are mostly classified into renewable and non-renewable resources. Renewable resources are defined by Salvati and Marco [37] as generally living resources for example, fish, elephants and forest, to name but a few. These can restock (renew) themselves if they are not over-harvested but used sustainably. Once renewable resources are consumed at a rate that exceeds their natural rate of replacement, the standing stock will diminish and eventually run out. The rate of sustainable use of a renewable resource is determined by the replacement rate and amount of standing stock of that particular resource.

Non-renewable resources is a natural resource that exists in a fixed amount that cannot be remade, regrown or regenerated as fast as it is consumed and made-up [38]. Although some non-renewable resources can be renewable but it takes extremely long time to renew. For example, fossil fuels take millions of years to form and so are not practically renewable.

\subsection{Natural Resources Governance Framework}

IUCN defines natural resources governance as: "The interactions among structures, processes and traditions that determine how power and responsibilities are exercised, how decisions are taken and how citizens or other stakeholders have their say in the management of natural resources including biodiversity conservation"'[39: p2].

Therefore in this regards Natural Resources Governance Framework (NRGF) addresses the set of norms, institutions and processes that frame decision making and critical engagement in policy development and how its implementation impact nature and people. Furthermore, NRGF provides a basis for understanding how governance at Lake Ngami affects livelihoods, food security as well as human wellbeing and how natural resources interventions can facilitate and support positive change [39].

\subsection{Application: Spatial and Temporal Dynamics of Lake Ngami}

Temporal remote sensing Google Earth [40] images were extracted as screen captures for specific dates (see Table 1) and georeferenced in ArcGIS 9.2 desktop software. Near anniversary images about the month of September, which are likely maximum spatial extent lake level as noted by Harebottle et al. [2], Stigand [4] and Schwarz [14] were used in the study.

Table 1. Google Earth Images used to map spatial extent of Lake Ngami.

\begin{tabular}{llll}
\hline Date & Month & Year & Cloud Cover (\%) \\
\hline 06 & August & 1979 & 0 \\
04 & September & 2003 & 0 \\
24 & September & 2004 & 0 \\
02 & November & 2006 & 0 \\
03 & August & 2007 & 0 \\
22 & September & 2011 & 0 \\
30 & September & 2014 & 0 \\
\hline
\end{tabular}

Source: [40]

The images used were clean and clear of clouds. However, there was a huge temporal gap between the first image and the second image of 14 years that leaves a void of understanding of the lake spatial extent. The images were downloaded based on available historic images using the Google Earth 'Time Slider" tool. Using visual image interpretation elements, water spatial extent were digitised for the images and a map for the specific time made. The lake spatial extent was extracted for the individual images. It is clearly evident that the lake levels and spatial extents vary as shown on Figure 7.

In the same vein, Harebottle et al. [2], Magole [3] and Larson [13] confirmed short term variability in the lake noting that during good rains season water level rises starting about June, to reach the peak in August and slowly decline in January. The spatial extent of the Lake Ngami as extracted from Google Earth images since 1979 to 2014 vary greatly. The lake changes in spatial extent hence the availability of water is critical as shown on the Figure 7. The large spatial extent noted for the year 2005 is also confirmed by Harebottle et al. [2] who noted that 1978/79 and 2004 were noted for high water extent in Lake Ngami. The recent 2014 spatial extent is one of the largest lake levels noted in this study. It is clearly evident that the selected maps of spatial extent for the lake agree with the record of Harebottle et al. [2] for the two situations and obviously 2014 was well after their publication. It is privy to also try to understand the population dynamics in the changes to help understand how to formulate policy that helps preserve biodiversity. Using such information as extracted using spatial technologies, the availability of the water resource for utilisation can be better informed by the maps. As shown on Figure 7, the spatial and temporal changes on the water resource are clearly evident. With this background and the further realisation of the habitation of the lake shown by modern settlements, the lake is predominantly a source of support for many human activities. The lake is surrounded by a total of 679 gardens (green polygons on Figure 8), which shows some spatial changes with some of the gardens as shown in green right round the lake. 


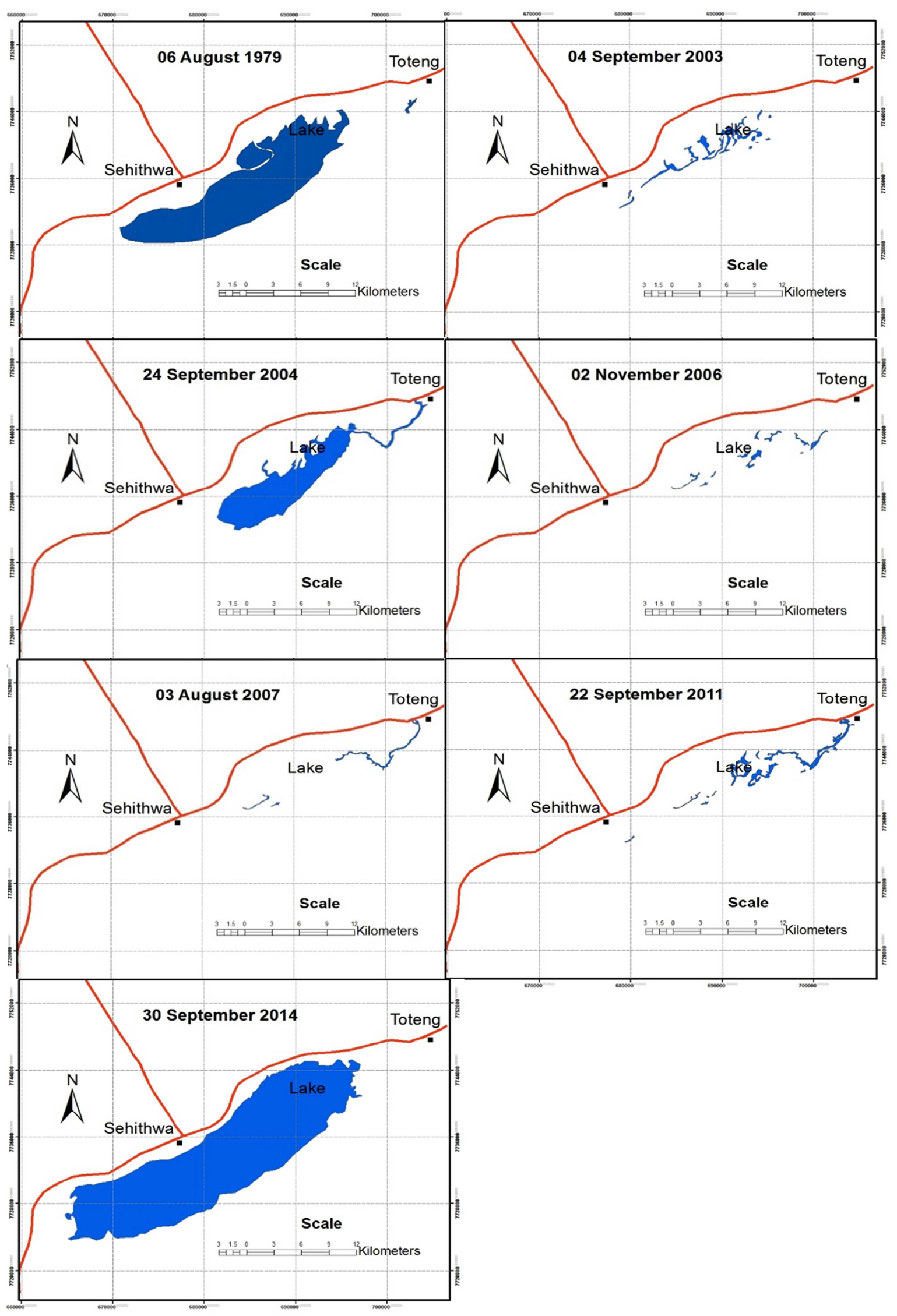

Figure 7. Spatio-temporal change of Lake Ngami for selected dates (1979-2014). 


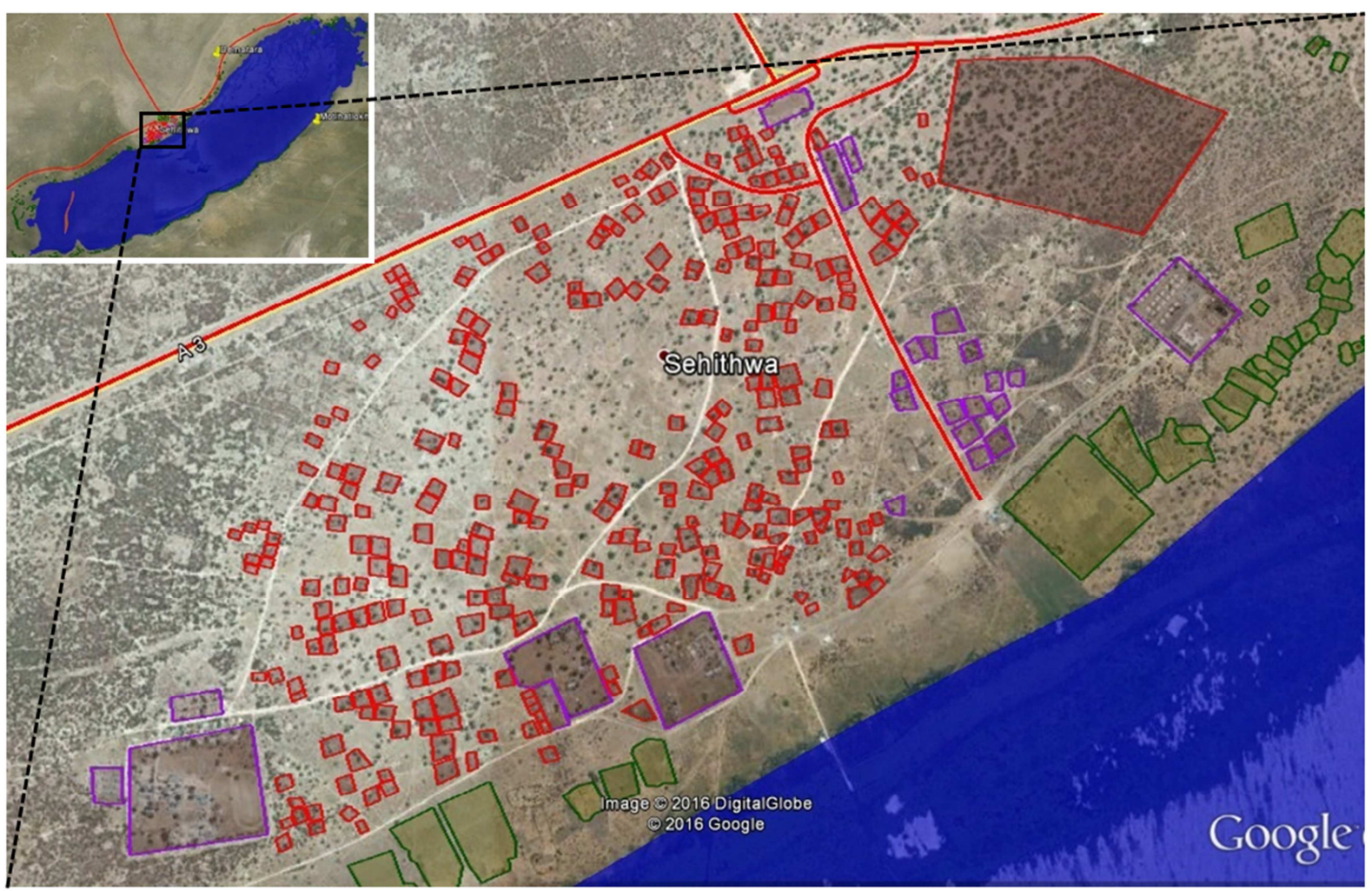

Figure 8. Human occupation and activities at Sehithwa.

The Google Earth image of 30 September 2014, shows a total of 309 western buildings (in red polygons), 31 building complexes (in purple polygons) were visually extracted on the northern shore of the lake at Sehithwa. The human activities at Sehithwa show predominance of humans on the water resource. There are gardens (green polygons), modern western buildings (within red polygons) and modern building complexes (purple polygons) around Lake Ngami (blue). Roads are shown in red and footpaths in white. It is apparently clear that any spatial planning and policy should take cognisance of the fact of increasing human presence at the shores of the lake. Although people have always been utilising the resource, it is important to note the sustainability of the lake in view of the current sustainable development goals. Human settlements as illustrated using the Sehithwa settlement implies that waste generation and disposal are critical and have to be seriously considered. Solid liquid and gaseous wastes are produced at the modern site and their disposal is a critical concern for spatial resource governance to ensure its sustainability.

The presence of gardens also implies eutrophication of the water body that promotes the proliferation of aquatic macrophytes that affects negatively, the critical water resource. Vegetable gardens use fertilisers and the erosion of these results in the deposition of the fertilisers in the water body. The rate at which settlements around Lake Ngami show that human occupation is increasing rapidly. This also has to be considered in the governance of the lake as a critical water body. The effects of man on the plant and animal life forms are important and spatial technology is one of the keys to understand the dynamics in the ecosystem. The habitation of the area of the lake implies important changes to the balance of nature especially with the introduction of western technologies and lifestyles. Land, water and air pollution become important concerns which can utilise spatial technologies in the management of the critical water resource.

Table 2. Selected Birds in and around Lake Ngami.

\begin{tabular}{ll}
\hline Bird Species & Estimated Population \\
\hline Red-billed Teal & 500000 \\
Hottentot Teal & 7000 \\
African Spoonbill & 600 \\
Collared Pratincole & 10000 \\
Whiskered Terns & 1000 \\
\hline
\end{tabular}

Source: [2: p2]

Table 2 shows the lake has an important ecosystem function in support of biodiversity and in this case, birds. Clearly, the Red-billed Teal is the most populous species in the lake area. While the table shows some selected bird species, it is clearly evident that this list is not exhaustive of the various bird species in the lake area. Harebottle et al. [2] (2006) recorded 231 bird species in their survey on bird ringing and about half the sample was waterbird species. Andersson [15-16] presented a much more detailed list of various biodiversity in and around Lake Ngami. Robbins et al. [17] used archaeological evidence to prove abundance of organisms both terrestrial and acquatic around the Ngami area. Owing to the importance of the lake in support of bird life, [2] Harebottle et al. (2006) therefore also noted that 
Lake Ngami is designated as important bird area in Botswana. Magole [3] indicated that the lake is a sanctuary of birds and wildlife. Tourism near Ngami is therefore significantly symbolised using bird names and images. The fluctuation of the lake water level is also noted to be proportional to bird populations. This obviously reveals that during drought, some species die. Schwarz [14] recorded that huge numbers of fish die and rot when the lake dries in.

Figure 9 shows birds that are part of the Lake Ngami ecosystem. Such are the birds as noted in several studies [2]. The lake is speculated to form part of breeding ground for various species especially water birds. These depend on the important water body for their survival. Pollution of the resource should thus be closely monitored and managed. Stigand [4] noted that oral evidence proved changing water courses due to siltation hence resource degradation. Furthermore, Mmualefe and Torto [41] recorded high $\mathrm{pH}$ pollution level of Lake Ngami. Policy on the utilisation, conservation and management of the lake is therefore of paramount significance.

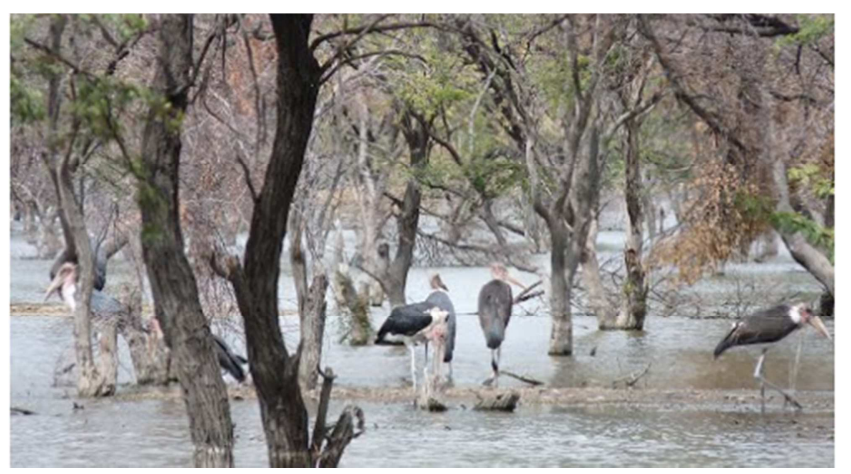

Figure 9. Birds in Lake Ngami, Source: [42].

Amongst the critical concerns is the distance away from the water body that should be allowed to develop in view of pollution challenges. What activities to allow at the upstream of the lake to ensure the sustainability of the lake. In cognisance of the fact that also humans have to survive, the balance of the human activities and the life of the Lake Ngami are critical concerns for spatial policy formulation, implementation and evaluation.

\subsection{Link Between Natural Resources and Spatial Technologies}

Water in the north western part of Botswana is important especially because the part is arid. The exploitation of remote sensing data, GPS data and fieldwork is critical in natural resource management. Temporal remote sensing images can be used to map, monitor and evaluate resource. For instance satellite images can be acquired annually thereby enabling spatial extent mapping that is important to help the understanding of the spatial extent of the lake. With that spatial information, the evaluation of the availability of water for humans and both domestic and wild animals is facilitated. With the current on-going global warming, the use of such spatial data could also help understand even the effect of climate change on the important water resource. Nicholson [43] used lake level reconstructions of past climate based over the two centuries of archived and diarised accounts by different explorers including Lake Ngami revealed high variability of the volume of water [20]. Nicholson [44] also noted the climatic variability of Africa including Lake Ngami.

GIS is important especially in the creation of the database that shows how the lake is changing temporally. The database could include resources such as the aquatic and terrestrial ecosystems and resources linked to the water body. There are diverse resources linked to the lake. Querying of the created database using spatial and topological queries is important especially to the departments concerned with the management of the critical water resource. This is important especially in view of the tourism that is now evidently on the expansion especially as the lake is also part of the famous Okavango inland delta. Layers generated form the spatial data could be overlaid and the expansion or reduction in the spatial extent of the resource noted.

\subsection{Challenges of Spatial Science to Natural Resources Governance}

One of the important challenges includes the fast changing spatial technology. The turn-over is very fast and requires commitment to the acquisition and maintenance of the water resource. The data has to be correctly interpreted and integrated for meaningful results. The cost of the technology is also another important consideration. Cost of data, computers and the expertise (training and refresher courses) is prohibitive. It often takes a much longer time to trace small changes and requires huge volumes of resources for that. It requires committed and collaborative effort for government and other stakeholders to ensure there is availability of resources to support the critical water resources recognised internationally as an important site. Coordination and collaboration are key components to ensure that the challenges are minimised.

\section{Conclusion}

Lake Ngami is an important biodiversity hotspot. However, it is threatened by both natural and man-induced factors. The resources in and around the lake are obviously affected by weather-induced fluctuations in the temporal lake spatial extent and human activities. Interventions are necessary for the sustainability and spatial policy needs to be formulated using the information derived from spatial technologies including remote sensing, GPS and GIS. The conservation, preservation and management of resources in and around the lake should therefore be governed by the imminent and imperative spatial policy on resource governance. The power of spatial technologies can be exploited for the sustainability of the lake resources however notwithstanding the requirements of function GIS unit. Decision makers including government departments, touism authorities and other relevant stakeholders without 
the necessary technical and spatial skills and knowhow can be guided by spatial information as output from remote sensing, GPS and GIS to make scientifically correct decisions on resource governance. GIS output in form of maps can be simplified annotated and illustrated for easier comprehension. Therefore a spatial policy for natural resources governance in and around Lake Ngami is an overdue and indispensable tool for effective and sound sustainable management of the resources especially in view of the current spatial distribution of human activities and the ongoing climate change.

\section{References}

[1] E. Hellard, G. S. Cumming, A. Caron, et al., "Testing epidemiological functional groups as predictors of avian haemosporidia patterns in southern Africa". Ecosphere, 2016, 7(4): 1-17.

[2] D. M. Harebottle, P. D'arcy, P. Hancock, P. et al., "Report on a Waterbird Ringing Study at Lake Ngami, Botswana, 3-18 December 2005, African Waterbird Ringing Scheme", 2006.

[3] L. Magole, "The 'Shrinking Commons' in the Lake Ngami Grasslands, Botswana: The Impact of National Rangeland Policy", Development Southern Africa, 2009, 26(4), 611-626.

[4] A. G. Stigand, "Notes on Ngamiland", The Geographical Journal, 1912, 39(4): 376-379.

[5] P. Wolf and M. Murray-Hudson, "Recent changes in flooding in the Xudum distributary of the Okavango Delta and Lake Ngami, Botswana," South. African Journal. Scince, 2006.

[6] A. A. Mabuse, "Bambata pottery and the advent of pastoralism in Botswana: A case study of Toteng, Ngamiland, Botswana. B. A. Research Essay, University of Botswana, Gaborone, Botswana, 2004.

[7] P. A. Shaw, S. Stokes, D. S. G. Thomas, et al., "Paleoecology and age of a Quaternary high lake level in the Makgadikgadi Basin of the Middle Kalahari, Botswana", South African Journal of Science, 1997, 93: 273-276.

[8] P. Huntsman-Mapila, S. Ringrose, A. W. Mackay, et al., "Use of the geochemical and biological sedimentary record in establishing palaeoenironmen's and climate change in the Lake Ngami basin, N. W. Botswana", Quaternary International, 2006, 148: 51-64.

[9] P. A. Shaw, "Fluctuations in the level of Lake Ngami: the historical evidence", Botswana Notes and Records, 1983, 15: 79-84.

[10] J. Bock and S. E. Johnson (not dated) "The Okavango Delta Peoples of Botswana," Global Sojourns, online www.globalsojourns.com.

[11] A. G. Stigand, "Ngamiland", The Geographical Journal, 1923, 62(6): 40-419.

[12] Merron, G. S., Pack Hunting in two species of catfish, Clarias gariepinus and $C$. ngamensis, in the Okavango Delta, Botwsana, Journal of Fish Biology, 1993, 43: 575-584.

[13] T. J. Larson, "The Bayeyi of Ngamiland Botswana Notes and Records", 1989, 21: 23-42.
[14] E. H. L. Schwarz, "The Botletle River", The Geographical Journal, 1926, 67(6): 528-535.

[15] C. J. Andersson, "Explorations in South Africa, with Route from Walfisch Bay to Lake Ngami and Ascent of the Tiogé River", J. Royal Geographical Society of London, 1855, 25: 79-107.

[16] C. J. Andersson, Lake Ngami; Explorations and Discoveries, During Four Years' Wanderings in the Wilds of South Western Africa; Hurst and Blakkett Publishers, London, UK 1856, 632pp.

[17] L. H. Robbins, M. L. Murphy, G. A. Brook, et al., "Archaeology, Palaeoenvironment, and Chronology of the Tsodilo Hills White Paintings Rock Shelter, Northwest Kalahari Desert, Botswana", Journal of Archaeological Science, 2000, 27: 1085-1113.

[18] L. H. Robbins, A. C. Campbell, M. L. Murphy, et al., "The Advent of Herding in Southern Africa: Early AMS Dates on Domestic Livestock from the Kalahari Desert", Current Anthropology, 2005, 46(4): 671-677.

[19] L. H. Robbins, A. C. Campbell, M. L. Murphy, "Mogapelwa: Archaeology, Palaeoenvironment and Oral Traditions at Lake Ngami, Botswana", The South African Archaeological Bulletin, 2009, 64(189): 13-32.

[20] H. Hamandawana, F. Eckardt and R. Chanda, "Linking archival and remote sensed data for long term environmental monitoring", University of Botswana, Gaborone, Botswana, 2003.

[21] T. S. McCarthy, G. R. J. Cooper, P. D. Tyson and W. N. Ellery, "Seasonal Flooding in the Okavango Delta, Botswana Recent History and Future Prospects", South African Journal of Science, 2000, 96: 25-33.

[22] T. Kabii, "Replica of UNESCO's letter informing the Bureau of the accession of Botswana", Ramsar Convention Bureau, Rue Mauverney 28, CH-1196 Gland, 1997.

[23] S. Ringrose, C. Vanderpost and W. Matheson, "Use of Image Processing Techniques to determine the extent and possible Causes of Land management/fenceline Induced Degradation Problems in the Okavango Area, Northern Botswana", International Journal of Remote Sensing, 1997, 18(11): 2337-2364.

[24] O. Ransford, "David Livingstone: The Dark Interior", Camelot Press Ltd, Southampton, UK, 1978.

[25] P. M. Marther, Computer Processing of Remotely Sensed Images, John Wiley \& Sons, New York, USA, 1996, ......

[26] R. A. McDonald, "Corona: Success for Space Reconnaissance: A Look into the Cold War, and a Revolution for Intelligence", Photogrametric Engineering and Remote Sensing, 1995, 61(6): 689-720.

[27] G. T. Gray, H. Amadou, C. W. Eric and W. L. Ronald, "Use of Argon, Corona, and Landsat Imagery to Assess 30 years of Land Resource Changes in West-Central Senegal", Photogrametric Engineering and Remote Sensing, 2000, 66 (6): 727-735.

[28] John Bartholomew \& Co.: Map of Bechuanaland 1906, www.probertencyclopaedia.com

[29] Jacana Enterprises (Pty) Ltd http://www.jacanaent.com/Maps/Bots_Old/Bechuanaland\%20 1922.jpg 
[30] Jacana Enterprises (Pty) Ltd http://www.jacanaent.com/Maps/Bots_Old/Bechuanaland\%20 1932.jpg

[31] International Union for Conservation of Nature and Natural Resources (IUCN), Gland, 2010.

[32] S. Michael, M. F. Goodchild, and P. A. Longley, Geospatial Analysis: A Comprehensive Guide to Principles Techniques and Software Tools, Wiley, West Sussex, England, 2015.

[33] C. Korolenko, "Information Fusion and Geographic Information Systems", Springer, London, 2009.

[34] P, Schrenk, "Geographical Information Analysis", John Wiley and Sons, New Jersey, 2010.

[35] Collins English Dictionary, Complete 2012 Digital Edition, William Collins and Sons Co. Ltd, 2012.

[36] T. David, Spatial Policy Perspectives in UK, Springer, London, UK, 2014.

[37] M. L. Hunter, Fundamentals of Conservation Biology. Blackwell Science Inc., Cambridge, UK 2009.

[38] L. Salvati and Z. Marco, "Natural resource depletion and economic performance of local districts: suggestions from a within-country analysis", Journal of Sustainable Development and World Ecology, 2008, 15(6): 518-523.
[39] IUCN, International Union for Conservation of Nature and Natural Resources (IUCN), Natural Resource Governance Framework A knowledge product of the International Union for Conservation of Nature, not dated.

[40] Google Earth http://earth.google.com/

[41] L. C. Mmualefe, and N. Torto, 2011 "Water quality in the Okavango Delta", Water SA, 2011, 37(3):

[42] Adolphus, "The picture Lake Ngami with water 2012", http://www.tripmondo.com/botswana/botswana-general/sehith wa/ https://mw2.google.com/mwpanoramio/photos/medium/99411303.jpg

[43] S. E. Nicholson, "The nature of rainfall variability over Africa on time scales of decades to millennia", Global and Planetary Change, 2000, 26: 137- 158.

[44] S. E. Nicholson, 2001 "Climatic and environmental change in Africa during the last two centuries", Clim Res, 2001, 17: 123-144. 